\title{
PENGARUH GAYA KEPEMIMPINAN \\ TRANSFORMASIONAL DAN TRANSAKSIONAL \\ TERHADAP KINERJA KARYAWAN DIVISI SDM \\ PADA DINAS PEKERJAAN UMUM DAN PENATAAN RUANG PROVINSI SUMATERA BARAT
}

\author{
Rahmad Kadra, Febsri Susanti \\ Sekolah Tinggi Ilmu Ekonomi KBP \\ rahmadkadra21@gmail.com \\ febsrisusanti@akbpstie.ac.id
}

\begin{abstract}
In the problem of employee work performance in the West Sumatra industrial and trade department. In the company a productivity that does not support work productivity. the number of employees who do not understand the work done, employees are also not responsible for a job. because of the large amount of work done by employees given by superiors. The purpose of this study was to determine the effect of transformational leadership style and transactional leadership style on the employee performance of HR Division employees at the Department of Public Works of West Sumatra Spatial Planning. This type of research is quantitative. The population of this study were employees of the Human Resources Division of the Department of Public Works, West Sumatra Spatial Planning with 81 samples. Data is processed using multiple linear regression using a questionnaire. The results showed that transformational leadership style had a positive and significant effect on employee performance with a value of $t$ arithmetic 2,281>t table 1,990, and sig value 0,001 <0.05 and transactional leadership style had a positive and significant effect on employee performance decisions with 3,066 $t$ count, $>t$ table 1.990, and sig value $0.003<0.05$ and suggestions for further researchers to be able to use this research as a reference which will later provide a comparison in conducting further research
\end{abstract}

Keywords: Transformational Leadership Style, Transactional Leadership Style, Employee Performance

\section{PENDAHULUAN}

Suatu organisasi atau perusahaan akan berhasil atau bahkan gagal sebagian besar ditentukan oleh atasan. Fungsi atasan dalam suatu perusahaan sangat menentukan dalam pencapaian tujuan organisasi atau perusahaan. Berbagai jalan dilakukan seorang atasan untuk mempengaruhi anak buah agar dapat melakukan pekerjaan sesuai dengan rencana yang telah ditentukan, diantaranya dengan memberikan pujian, memberikan penghargaan, memberikan motivasi, dan dengan memberikan tekanan terhadap karyawan. 
Manusia adalah sumber daya yang berbeda dari faktor produksi lain nya karena mempuyai perasaan, pikiran, dan latarbelakang yang heterogen. Manusia juga memiliki kebutuhan yang tidak terbatas, artinya kebutuhan manusia selalu bertambah dari waktu ke waktu. Kebutuhan manusia diartikan sebagai segala sesuatu yang dimilikinya, dicapai, dan dinikmati, oleh karena itu manusia terdorong untuk melakukan kegiatan dengan bekerja.

Sumber daya manusia dalam perusahaan aspek penting yang menentukan keberhasilan suatu perusahaan. Perusahaan yang lengkap dengan saran dan prasaran tidak akan berarti tanpa adanya manusia sebagai pengolah dan pemuat gagasan.

Kinerja karyawan adalah pertimbangan kerja yang dilakukan pemimpin untuk melakukanpenilaian terhadap tiap-tiap anggota kelompok. Tidak hanya itu, tiap-tiap individu juga dilakukan penilaian kerja. Lingkup yang dipertimbagan antara lain hasil kerja anak buah tersebut apakah sesuai dengan incaran, standar, kriteria yangditetapkan perusahaan.

Gaya kepemimpinan adalah sekumpulan dari serangkaian kemampuan dan sifat-sifat kepribadian, termasuk didalamnya kewibawaan untuk dijadikan sebagai sarana dalam rangka meyakinkan yang dipimpinnya agar mereka mau dan dapat melaksanakan tugas-tugas yang dibebankan kepadanya dengan rela, penuh semangat, ada kegembiraan batin, serta merasa tidak terpaksa. Seorang pemimpin harus memiliki pemikiran yang bijak dan tegar agar lingkungan tersebut dapat terkendali misalnya dalam suatu perusahaan. Perusahaan yang mempunyai pemimpin baik maka perusahaan itu dapat dikelola dengan baik namun sebaliknya perusahaan yang mempunyai pemimpin buruk maka perusahaan tidak dapat mencapai keberhasilan dengan maksimal bahkan lebih buruk atau menyebabkan perusahaan bangkrut.

Seorang pemimpin dikatakan transformasional ketika dia mampu mengilhami bawahannya untuk menerima visi organisasi sebagai miliknya selagi berusaha untuk meningkatkan nilai-nilai organisasinya. Namun ada kontradiksi mengenai dampak gaya kepemimpinan transaksional dan transformasional terhadap kinerja organisasi. Beberapa studi tertentu Sardi (2017), telah mengindikasikan bahwa kepemimpinan transformasional memiliki dampak positif pada kinerja sementara kepemimpinan transaksional berdampak negatif.

Berdasarkan kajian literatur ada beberapa gaya kepemimpinan, diantaranya adalah kepemimpinan tranformasional dan kepemimpinan transaksional. Esensi pada kepemimpinan adalah upaya seseorang untuk mempegaruhi orang lain agar berprilaku sesuai dengan yang diinginkan olehnya. Dalam rangka mempengaruhi orang lain, seseorang mempunyai banyak pilihan gaya kepemimpinan yang akan digunakan. Salah satu gaya kepemimpinanyang relatif populer adalah kepemimpinan transformasional.

Laily (2017), gaya kepemimpinan transformasional ini bayangan sebagai pemimpin yang ingin mengembangkan potensi penuh bawahannya, kebutuhan yang lebih tinggi, sistem nilai yang baik, moralitas dan motivasi.

Menurut Indira (2017), kepemimpinan transaksional adalah gaya kepemimpinan dimana seorang pemimpin menfokuskan perhatiannya pada negosiasi interpersonal antara pemimpin dengan karyawan yang melibatkan hubungan pertukaran. Pertukaran tersebut didasarkan pada kesepakatan mengenai klasifikasi incaran, standar kerja, penugasan kerja, dan penghargaan. 
Kinerja menurut Italiani (2013), pengertiannya adalah hasil atau tingkat keberhasilan seseorang atau keseluruhan selama periode tertentu didalam melaksanakan tugas dibandingkan dengan berbagai kemungkinan, seperti hasil kerja, incaran atau sasaran atau patokan yang telah ditentukan terlebih dahulu dan telah disepakati bersama.

\section{METODE PENELITIAN}

\section{Populasi dan Sampel}

Pada penelitian ini populasinya adalah karyawan Dinas pekerjaan umum dan penataan ruang provinsi sumatra barat sebanyak 423 orang. Teknik penarikan sampel yang dipakai pada penelitian ini ialah dengan mungunakan rumus slovin. Rumus slovin adalah teknik untuk menentukan sampel dari populasi yang mempunya ciri-ciri tertentu sampai jumlah yang telah ditetapkan oleh peneliti sebagai batasannya.

Pada penelitian ini, jumlah sampel yang dipakai oleh peneliti sebanyak 81 responden, jumlah tersebut merupakan jumlah sampel diatas minimal agar terhindar dari sampel error

\section{JENIS DAN SUMBER DATA}

Jenis data yang dipakai pada penelitian ini adalah data kuantitatif. Data kuantitatif merupakan data yang diperoleh dari metode survei dan eksperimen. Menurut Sugiyono (2015) metode penelitian yang berlandaskan pada filsafat positivisme, digunakan untuk meneliti pada populasi atau sampel tertentu, pengumpulan data mengunakan instrument penelitian disebut dengan data kuantitatif. Tujuan analisis data kuantitatif adalah untuk menguji hipotesisis yang telah ditetapkan.Sedangkan sumber data yang dipakai pada penelitian ini ialah data primer. Data primer dalam penelitian ini diperoleh melalui pengisian kuesioner.

\section{HASIL DAN PEMBAHASAN \\ Karakteristik Responden \\ 1. Jenis Kelamin Responden}

\section{Tabel 1}

Karakteristik Responden Berdasarkan Jenis Kelamin

\begin{tabular}{ccc}
\hline Jenis Kelamin & Frekuensi (Orang) & Persentase \\
\hline Laki-Laki & 57 & 70,4 \\
\hline Perempuan & 24 & 29,6 \\
\hline Total & 81 & 100 \\
\hline
\end{tabular}

Sumber: Hasil Analisis Data Penelitian Th.2018

Diperoleh data dari 81 responden. Responden didinas pekerjaan umum dan penataan ruang provinsi sumatera barat adalah menjelaskan bahwa komposisi jenis kelamin responden, dimana 57 orang $(70,4 \%)$ responden adalah laki-laki dan sebanyak 24 orang $(29,6 \%)$ adalah perempuan. Jadi dapat disimpulkan jenis kelamin laki-laki paling banyak pada penelitian ini. 


\section{Umur Responden}

Tabel 2

Karakteristik Responden Berdasarkan Umur

\begin{tabular}{lcc}
\hline \multicolumn{1}{c}{ Umur } & Frekuensi (Orang) & Persentase \\
\hline$<25$ Tahun & 2 & 2,5 \\
\hline 25-31 Tahun & 11 & 13,6 \\
\hline 32-37 Tahun & 39 & 48,1 \\
\hline 38-43 Tahun & 18 & 22,2 \\
\hline$>44$ Tahun & 11 & 13,6 \\
\hline \multicolumn{1}{c}{ Total } & 81 & $100 \%$ \\
\hline
\end{tabular}

Sumber: Hasil Analisis Data Penelitian Th.2018

Diperoleh data dari 81 responden. Responden didinas pekerjaan umum dan penataan ruang provinsi sumatera barat adalah menjelaskan bahwa komposisi umur responden, dimana 2 orang $(2,5 \%)$ responden dengan umur $<25$ tahun, sebanyak 11 orang $(13,6 \%)$ dengan umur 25-31 tahun dan $>44$ tahun, sebanyak 39 orang $(48,1 \%)$ responden dengan umur 32-37 tahun dan sebanyak 18 orang $(22,2 \%)$ dengan umur 38,43 tahun . Jadi dapat disimpulkan umur responden paling banyak adalah 32-37 tahun.

\section{Pendidikan Responden}

Tabel 3

Karakteristik Responden Berdasarkan Pendidikan Terakhir

\begin{tabular}{|c|c|c|}
\hline Pendidikan Terakhir & Frekuensi (Orang) & Persentase (\%) \\
\hline D3 & 9 & 11,1 \\
\hline S1 & 51 & 63 \\
\hline S2 & 21 & 25,9 \\
\hline Total & 81 & 100 \\
\hline
\end{tabular}

Sumber: Hasil Analisis Data Penelitian Th.2018

Diperoleh data dari 81 responden. Responden didinas pekerjaan umum dan penataan ruang provinsi sumatera barat adalah menjelaskan bahwa pendidikan terakhir D3 sebanyak 9 orang $(11,1 \%)$, S1 sebanyak 51 orang (63) dan pendidikan S2 sebanyak 21 orang $(25,9 \%)$. Jadi dapat disimpulkan bahwa karyawan paling banyak dengan pendidikan $\mathrm{S} 1$.

\section{Lama Bekerja Responden}

Tabel 4

Karakteristik Responden Berdasarkan Lama Bekerja

\begin{tabular}{ccc}
\hline Pendidikan Terakhir & Frekuensi (Orang) & Persentase (\%) \\
\hline 1-3 Tahun & 16 & 19,8 \\
\hline 4-6 Tahun & 42 & 51,9 \\
\hline >7 Tahun & 23 & 28,4 \\
\hline Total & 81 & 100
\end{tabular}

Sumber: Hasil Analisis Data Penelitian Th.2018

Diperoleh data dari 81 responden. Responden didinas pekerjaan umum dan penataan ruang provinsi sumatera barat menjelaskan bahwa sebanyak 16 orang $(19,8 \%)$ dengan lama bekerja 1-3 tahun, sebanyak 42 orang $(51,9 \%)$ dengan lama bekerja 4-6 tahun dan sebanyak 23 orang $(28,4 \%)$ dengan lama bekerja $>7$ tahun. Jadi dapat disimpulkan bahwa karyawan paling banyak dengan lama bekerja 4-6 tahun. 


\section{Gaya kepeminpinan Transformasional (X1)}

Tabel 5

Hasil Uji Validitas Gaya kepeminpinan Transformasional (X1)

\begin{tabular}{cccl}
\hline Variabel & $\begin{array}{c}\text { Corrected Item- } \\
\text { Total Correlation }\end{array}$ & Batas Nilai & Keterangan \\
\hline 1 & 0.681 & 0.300 & Valid \\
\hline 2 & 0.528 & 0.300 & Valid \\
\hline 3 & 0.509 & 0.300 & Valid \\
\hline 4 & 0.595 & 0.300 & Valid \\
\hline 5 & 0.384 & 0.300 & Valid \\
\hline 6 & 0.688 & 0.300 & Valid \\
\hline 7 & 0.653 & 0.300 & Valid \\
\hline 8 & 0.609 & 0.300 & Valid \\
\hline 9 & 0.487 & 0.300 & Valid \\
\hline 10 & 0.327 & 0.300 & Valid
\end{tabular}

Sumber: Data Primer diolah dengan SPSS Th.2018

Berdasarkan data Tabel 5 hasil pengujian validitas variabel gaya kepemimpinan transformasional yang dirancang dengan 10 item pernyataan, secara keseluruhan 10 item pertanyaan sudah bernilai valid, hal ini ditunjukan oleh nilai corrected item total correlation $>0,300$

2. Gaya Kepemimpinan Transaksional (X2)

Tabel 6

Hasil Uji Validitas Gaya Kepemimpinan Transaksional

\begin{tabular}{cccc}
\hline Variabel & $\begin{array}{c}\text { Corrected Item-Total } \\
\text { Correlation }\end{array}$ & Batas Nilai & Keterangan \\
\hline 1 & 0.908 & 0.300 & Valid \\
\hline 2 & 0.510 & 0.300 & Valid \\
\hline 3 & 0.441 & 0.300 & Valid \\
\hline 4 & 0.790 & 0.300 & Valid \\
\hline 5 & 0.878 & 0.300 & Valid \\
\hline 6 & 0.737 & 0.300 & Valid \\
\hline
\end{tabular}

Sumber: Data Primer diolah dengan SPSS Th.2018

Berdasarkan data Tabel 6 hasil pengujian validitas variabel gaya kepemimpinan transaksional yang dirancang dengan 6 item pernyataan, secara keseluruhan semua item pertanyaan sudah bernilai valid, hal ini ditunjukan oleh nilai corrected item total corelation $>0,300$. 
3. Kinerja Karyawan (Y)

Tabel 7

Hasil Uji Validitas Kinerja Karyawan

\begin{tabular}{cccc}
\hline Variabel & $\begin{array}{c}\text { Corrected Item-Total } \\
\text { Correlation }\end{array}$ & Batas Nilai & Keterangan
\end{tabular}

\begin{tabular}{llll}
\hline 1 & 0.599 & 0.300 & Valid \\
\hline 2 & 0.541 & 0.300 & Valid \\
\hline 3 & 0.776 & 0.300 & Valid \\
\hline 4 & 0.612 & 0.300 & Valid \\
\hline 5 & 0.502 & 0.300 & Valid \\
\hline 6 & 0.787 & 0.300 & Valid \\
\hline 7 & 0.588 & 0.300 & Valid \\
\hline 8 & 0.603 & 0.300 & Valid \\
\hline 9 & 0.650 & 0.300 & Valid \\
\hline 10 & 0.562 & 0.300 & Valid \\
\hline 11 & 0.473 & 0.300 & Valid \\
\hline 12 & 0.585 & 0.300 & Valid \\
\hline
\end{tabular}

Sumber: Data Primer diolah dengan SPSS Th.2018

Berdasarkan data Tabel 7 hasil pengujian validitas variabel kinerja karyawan yang dirancang dengan 12 item pernyataan, secara keseluruhan semua item pertanyaan sudah bernilai valid, hal ini ditunjukan oleh nilai corrected item total corelation $>0,300$.

Uji Reliabilitas

Tabel 8

Hasil Uji Reliabilitas

\begin{tabular}{cccc}
\hline Variabel & $\begin{array}{c}\text { Cronbach's } \\
\text { Alpha }\end{array}$ & $\begin{array}{c}\text { Batas } \\
\text { Nilai }\end{array}$ & Keterangan \\
\hline Gaya kepemimpinan transformasional & 0,844 & 0,600 & Reliabel \\
\hline Gaya kepemimpinan transaksional & 0,889 & 0,600 & Reliabel \\
\hline Kinerja karyawan & 0,893 & 0,600 & Reliabel \\
\hline
\end{tabular}

Sumber: Data Primer diolah dengan SPSS Th.2018

Berdasarkan data Tabel 8 hasil pengujian masing-masing variabel secara keseluruhan semua item pertanyaan sudah bernilai reliabel, hal ini ditunjukan oleh nilai koefisien korelasi (r) diatas 0,60.

\section{Analisis Deskriptif TCR}

\section{Gaya kepemimpinan transformasional (X1)}

Berdasarkan hasil pengujian menemukan bahwa total skor dari variabel gaya kepemimpinan transformasional memiliki nilai TCR sebesar 78,25\% dengan Rata-Rata 3,91 dimana nilai tersebut termasuk dalam kategori setuju. Hal tersebut dapat disimpulkan bahwa responden setuju dengan gaya kepemimpinan transformasional.

Berdasarkan hasil analisis yang telah dilakukan dari 10 item pernyataan mengenai gaya kepemimpinan transformasional yang memiliki skor rata-rata tertinggi adalah pernyataan nomor delapan dengan nilai Rata-Rata 4,05 dengan 
Tingkat Capaian Responden 80,99\%, Sedangkan nilai Rata-Rata Terendah adalah pertanyaan nomor dua dengan nilai Rata-Rata 3,72 dengan Tingkat Capaian Responden $74,32 \%$, dimana hasilnya setuju.

\section{Gaya kepemimpinan transaksional}

Berdasarkan hasil pengujian menemukan bahwa total skor dari variabel gaya kepemimpinan transaksional memiliki nilai TCR sebesar 80,82\% dengan Rata-Rata 4,04 dimana nilai tersebut termasuk dalam kategori setuju. Hal tersebut dapat disimpulkan bahwa responden setuju dengan gaya kepemimpinan transaksional.

Berdasarkan hasil analisis yang telah dilakukan dari 6 item pernyataan mengenai gaya kepemimpinan transaksional yang memiliki skor rata-rata tertinggi adalah pernyataan nomor lima dengan nilai Rata-Rata 4,12 dengan Tingkat Capaian Responden 82,47\%, Sedangkan nilai Rata-Rata Terendah adalah pertanyaan nomor empat dengan nilai Rata-Rata 3,91 dengan Tingkat Capaian Responden 78,27\%, dimana hasilnya setuju.

\section{Kinerja Karyawan}

Berdasarkan hasil pengujian menemukan bahwa total skor dari variabel kinerja karyawan memiliki nilai TCR sebesar 75,12\% dengan Rata-Rata 3,76 dimana nilai tersebut termasuk dalam kategori setuju. Hal tersebut dapat disimpulkan bahwa responden setuju dengan kinerja karyawan.

Berdasarkan hasil analisis yang telah dilakukan dari 12 item pernyataan mengenai kinerja karyawan yang memiliki skor rata-rata tertinggi adalah pernyataannomor tiga dengan nilai Rata-Rata 4,16 dengan Tingkat Capaian Responden 83,21\%, Sedangkan nilai Rata-Rata Terendah adalah pertanyaan nomor lima dengan nilai Rata-Rata 3,28 dengan Tingkat Capaian Responden $65,68 \%$, dimana hasilnya setuju.

\section{Asumsi Klasik}

\section{Uji normalitas}

Uji Normalitas bertujuan untuk menguji apakah dalam suatu model regresi mempunyai distribusi yang normal. Dalam penelitian ini digunakan uji One Sample Kolmogorov-Smirnov. Uji One Sample Kolmogorov-Smirnov dasar keputusannya adalah berdasarkan probabilitas (asymptotic significance), yaitu jika pvalue $>0,05$ maka dapat disimpulkan data tersebut bernilai normal.

\section{Uji Multikolinearitas}

Berdasarkan hasil pengolahan data dapat dilihat bahwa masing-masing variabel independen memiliki nilai tolerance $>0.1$, dan masing-masing variabel independent VIF $<10$ berdasarkan hasil pengolahan data diatas maka dapat disimpulkan bahwa penelitian ini terbebas dari masalah Multikolinearitas.

\section{Uji Heteroskedastisitas}

Berdasarkan hasil uji heteroskedastisitas dapat diketahui bahwa nilai signifikan variabel gaya kepemimpinan trasnformasional dan gaya kepemimpinan transaksional nilai semuanya $>0,05$. Jadi dapat disimpulkan bahwa semua nilai variabel terbebas dari gejala heteroskedastisitas.

\section{Uji Regresi Linear Berganda}

Berdasarkan hasil yang terdapat maka dapat dirumuskan persamaan regresi linear berganda sebagai berikut:

$$
\mathrm{Y}=23,984+0,298 \mathrm{X}_{1}+0,388 \mathrm{X}_{2}+\mathrm{e}
$$


1. Dari model persamaan regresi linear berganda di atas dapat diketahui bahwa nilai konstanta sebesar 23,984, yang berarti bahwa tanpa adanya pengaruh dari variable gaya kepemimpinan transformasional dan gaya kepemimpinan transaksional maka kinerja karyawan sudah mencapai 23,984 satuan.

2. Koefisien regresi variabel gaya kepemimpinan transformasional $\left(X_{1}\right)$ sebesar 0,298 . Hal ini berarti apabila gaya kepemimpinan transformasionalmeningkat sebesar satu satuan maka kinerja karyawanakan meningkat sebesar 0,298 dalam setiap satuannya. Dengan asumsi variabel lain tidak mengalami perubahan atau konstan.

3. Koefisien regresi variabel gaya kepemimpinan transaksional $\left(\mathrm{X}_{2}\right)$ sebesar 0,388 . Hal ini berarti apabila gaya kepemimpinan transaksionalmeningkat sebesar satu satuan maka kinerja karyawanakan meningkat sebesar 0,388 dalam setiap satuannya. Dengan asumsi variabel lain tidak mengalami perubahan atau konstan.

\section{Koefisien Determinasi $\mathbf{R}^{2}$}

Berdasarkan dapat terlihat bahwa besarnya nilai $\mathrm{R}$ Square (dilihat dari Adjusted $\mathrm{R}$ square) sebesar 0,267. Hal ini berarti 26,7\% kinerja karyawan dipengaruhi oleh gaya kepemimpinan transformasional dan gaya kepemimpinan transaksional sedangkan sisanya 73,3\% disebabkan oleh hal-hal lain yang ada diluar penelitian seperti lingkungan kerja dan motivasi kerja.

\section{Uji Hipotesis (Uji T)}

Berdasarkan hasil pengolahan data hasil uji $\mathrm{t}$ parsial, maka dapat disimpulkan bahwa:

1. Bahwa gaya kepemimpinan transformasional memiliki nilai koefisien regresi positif dengan nilai t hitung sebesar 3,560 dengan nilai sig sebesar 0,001. Jika dibandingkan dengan ( $\mathrm{t}$ tabel, sig 0.05 , df $(81-2)=79$. Maka dapat terlihat bahwa dengan nilai $t$ hitung 2,281 $>\mathrm{t}$ tabel 1,990 , dan nilai sig $0,001<0.05$, maka dapat disimpulkan bahwa Ha diterima dan Ho ditolak artinya bahwa gaya kepemimpinan transformasional berpengaruh positif dan signifikan terhadap kinerja karyawan karyawan.

2. Bahwa gaya kepemimpinan transaksional memiliki nilai koefisien regresi positif dengan nilai t hitung sebesar 3,066 dengan nilai sig sebesar 0,003. Jika dibandingkan dengan (t tabel, sig 0.05 , df $(81-2)=79$ ). Maka dapat terlihat bahwa dengan nilai t hitung 3,066, $>\mathrm{t}$ tabel 1,990, dan nilai sig $0,003<0.05$, maka dapat disimpulkan bahwa Ha diterima dan Ho ditolak artinya bahwa gaya kepemimpinan transaksional berpengaruh positif dan signifikan terhadap keputusan kinerja karyawan.

\section{PEMBAHASAN}

1. Pengujian gaya kepemimpinan transformasionalterhadap kinerja karyawan karyawan pada Divisi SDM pada Dinas Pekerjaan Umum Penataan Ruang Provinsi Sumatera Barat.

Berdasarkan penelitian diperoleh hasil nilai t hitung 2,281>t tabel 1,990, dan nilai sig $0,001<0.05$, maka dapat disimpulkan bahwa Ha diterima dan Ho ditolak artinya bahwa gaya kepemimpinan transformasional berpengaruh positif dan signifikan terhadap kinerja karyawan karyawan.

Sejalan dengan penelitian sebelumnya yang dilakukan oleh Novitasari (2016), dalam penelitian yang berjudul Pengaruh Gaya Kepemimpinan 
Transformasional dan Motivasi Kerja Terhadap Kinerja Karyawan. Hasil pengujian hipotesis pertama menunjukkan gaya kepemimpinan transformasional berpengaruh signifikan terhadap kinerja karyawan, hal ini menunjukkan semakin tepat gaya kepemimpinan, maka kinerja anak buah juga akan meningkat.

Kepemimpinan transformasional merupakan kemampuan untukmemberikan buah pikiran dan memotivasi para pengikutnya untuk mencapai hasil hasil yang lebih besar daripada yang direncanakan secara orisinil dan untuk imbalan internal (Mondiani, 2012).Gaya kepemimpinan transformasional memiliki pertalian yang sangat kuat dan menjadi poin penting yang mempengaruhi berbagai aspek termasuk komitmen organisasi dan kinerja karyawan.Oleh karena itu karakter pemimpin yang kuat dan baik merupakan modal yang baik untuk mendapatkan kinerja karyawan yang baik serta komitmen organisasi yang kuat.

Mowday et al. (1979) dalam Nugroho (2011) mendefinisikan komitmen organisasional sebagai kekuatan relatif dari identifikasi individu dan keterlibatan dalam organisasi khusus, meliputi kepercayaan, dukungan terhadap tujuan dan nilai-nilai organisasi dan keinginan yang kuat untuk menggunakan upaya yang sungguh-sungguh untuk kepentingan organisasi dan kemauan yang kuat untuk menjaga keanggotaan dalam organisasi. Komitmen organisasi terkait dengan keterkaitan batin jarak karyawan dengan organisasi dimana secara tidak sadar seorang karyawan akan mencerminkan nilai-nilai perusahaan dalam kehidupan sehari-hari dan kecenderungan untuk membanggakan organisasinya kepada orang lain.

2. Pengujian gaya kepemimpinan transaksionalterhadap kinerja karyawan karyawan pada Divisi SDM pada Dinas Pekerjaan Umum Penataan Ruang Provinsi Sumatera Barat.

Berdasarkan penelitian diperoleh hasil gaya kepemimpinan transaksional memiliki nilai koefisien regresi positif dengan nilai $t$ hitung sebesar 3,066dengan nilai sig sebesar 0,003. Jika dibandingkan dengan ( $\mathrm{t}$ tabel, sig 0.05 , df $(81-2)=79)$. Maka dapat terlihat bahwa dengan nilai t hitung 3,066, > t tabel 1,990, dan nilai sig $0,003<0.05$, maka dapat disimpulkan bahwa $\mathrm{Ha}$ diterima dan Ho ditolak artinya bahwa gaya kepemimpinan transaksional berpengaruh positif dan signifikan terhadap keputusan kinerja karyawan.

Sejalan dengan penelitianDamayanti (2017), dalam penelitian yang berjudul Pengaruh Kepemimpinan Transformasional Kepemimpinan Transaksional dan Lingkungan Kerja terhadap Kinerja Karyawan. Pengujian hipotesis menggunakan uji Kelayakan Model diketahui nilai signifikansi lebih kecil dari tingkat signifikansi maka hal ini berarti kepemimpinan transformasional, kepemimpinan transaksional, dan lingkungan kerja berpengaruh signifikan terhadap kinerja karyawan PD Garuda Surabaya.

Luthans (2006), menyatakan bahwa kepemimpinan transformasional membawa keadaan menuju kinerja tinggi pada organisasiyang menghadapi tuntutan pembaharuan dan perubahan.Simamora (2006) menyampaikan bahwa kinerja (performance) mengacu kepada ukuran pencapaian tugas-tugas yang membentuk sebuah pekerjaan karyawan dan merefleksikan seberapa baik karyawan memenuhi persyaratan sebuah pekerjaan, namun sering disalah 
pengertian sebagai upaya (effort) yang mencerminkan energi yang dikeluarkan, kinerja diukur dari segi hasil.

Verda Khan et al (2012) menyatakan bahwa Gaya kepemimpinan transformasional lebih fleksibel meningkatkan kreativitas karyawan dan otonomi oleh karena itu kinerja karyawan meningkat. Penelitian Indica (2013) menguatkan dengan kesimpulan gaya kepemimpinan transformasional berpengaruh positif dan signifikan terhadap kinerja karyawan pada Waroeng Steak and Shake di Kota Malang. Penelitian tersebut juga diperkuat oleh Sarwat (2011) yang menyatakan bahwa kepemimpinan transformasional memiliki hubungan yang kuat dan signifikan mengacu kepada analisis korelasi kita, yang menunjukkan bahwa gaya kepemimpinan yang diinginkan adalah gaya kepemimpinan transformasional, gaya kepemimpinan tersebut meningkatkan kinerja organisasi.

\section{SIMPULAN}

Berdasarkan hasil pengujian dan pembahasan mengenai Pengaruh Gaya Kepemimpinan Transformasional dan Gaya Kepemimpinan Transaksional Terhadap kinerja karyawan Karyawan Divisi SDM pada Dinas Pekerjaan Umum Penataan Ruang Provinsi Sumatera Barat, maka dapat ditarik kesimpulan, antara lain:

1. Gaya kepemimpinan transformasional memiliki nilai koefisien regresi positifdengan nilai t hitung sebesar 3,560 dengan nilai sig sebesar 0,001. Jika dibandingkan dengan ( $\mathrm{t}$ tabel, sig 0.05 , df $(81-2)=79$. Maka dapat terlihat bahwa dengan nilai $t$ hitung 2,281 $>\mathrm{t}$ tabel 1,990 , dan nilai sig $0,001<0.05$, maka dapat disimpulkan bahwa Ha diterima dan Ho ditolak artinya bahwa gaya kepemimpinan transformasional berpengaruh positif dan signifikan terhadap kinerja karyawan karyawan.

2. Gaya kepemimpinan transaksional memiliki nilai koefisien regresi positif dengan nilai $\mathrm{t}$ hitung sebesar 3,066 dengan nilai sig sebesar 0,003. Jika dibandingkan dengan ( $\mathrm{t}$ tabel, sig 0.05, df $(81-2)=79)$. Maka dapat terlihat bahwa dengan nilai $t$ hitung 3,066, $>\mathrm{t}$ tabel 1,990, dan nilai sig $0,003<0.05$, maka dapat disimpulkan bahwa Ha diterima dan Ho ditolak artinya bahwa gaya kepemimpinan transaksional berpengaruh positif dan signifikan terhadap keputusan kinerja karyawan.

\section{UCAPAN TERIMA KASIH}

Selesainya penulisan ini, karena penulis banyak menerima masukan dan dorongan baik motivasi secara moral atau spiritual. Oleh karena itu penulis ingin mengucapkan terimakasih kepada Bapak Ir. Fathol Bari, M.sc. Eng kepala Dinas Pekerjaan Umum dan Penataan Ruang Provinsi Sumatera Barat. Yang telah menerima saya untuk melakukan penelitian danIbu Febsri Susanti, SEI, MM. sebagai dosen pembimbing dalam pembuatan skripsi ini dan penulis banyak berterima kasih atas kesabaran, kepedulian dan kesempatan yang sudah diberikan, penulis berharap kebaikan ibu bisa dibalas oleh Tuhan Yang Maha Esa. Selanjutnya terima kasih juga kepada Seluruh bagian yang sudah banyak menolong penulis yang tidak dapat penulis sampaikan satu persatu 


\section{DAFTAR PUSTAKA}

Damayanti, N. (2017). Pengaruh Kepemimpinan Transformasional, Kepemimpinan Transaksional Dan Lingkungan Kerja Terhadap Kinerja Karyawan. Jurnal Ilmu Dan Riset Manajemen, 6(11).

Indira, diah ayu rachmi. (2017). Pengaruh Gaya Kepemimpinan Transformasional Dan Transaksional Terhadap Kinerja Karyawan Divisi Sdm Pt.Pelindo Iii Cabang Tanjung Perak Surabaya. Jurnal Ilmu Manajemen, 5(1), 1-7.

Italiani, F. A. (2013). Pengaruh Gaya Kepemimpinan Transformasional Dan Transaksional Terhadap Kinerja Pegawai Departemen Sdm Pt. Semen Gresik (Persero) Tbk. Jurnal Ilmu Manajemen, 1(2).

Junaidi, R., \& Susanti, F. (2019). Pengaruh Gaya Kepemimpinan Dan Budaya Organisasi Terhadap Kinerja Pegawai Pada UPTD Baltekkomdik Dinas Pendidikan Provinsi Sumatera Barat. https://doi.org/10.31227/osf.io/bzq75

Laily, N. (2017). Pengaruh Gaya Kepemimpinan Transformasional Dan Komitmen Organisasi Terhadap Kinerja Karyawan (Studi Kasus Karyawan Bagian Kantor Pada Pt. Agung Automall Pekanbaru) Oleh. Jom FISIP Volume, 4(2), 1-10.

Lubis, A. Y. O., \& Susanti, F. (2019). Pengaruh Gaya Kepemimpinan Dan Kompensasi Terhadap Prestasi Kerja Karyawan (Studi pada PT Japfa Comfeed Indonesia (JCI) Tbk Devisi Fam 1. https://doi.org/10.31227/osf.io/7tbrg

Mayliza, R. (2019). Pengaruh Gaya Kepemimpinan Dan Disiplin Kerja Terhadap Kinerja Karyawan Dengan Motivasi Kerja Sebagai Variabel Intervening Pada PT. Semen Padang. https://doi.org/10.17605/OSF.IO/FYPQ9.

Mayliza, R. (2019). Pengaruh Gaya Kepemimpinan Dan Disiplin Kerja Terhadap Kinerja Pegawai, Dengan Motivasi Kerja Sebagai Variabel Intervening (Studi Pada Dinas Pendidikan Kabupaten Tanah Datar). https://doi.org/10.17605/OSF.IO/JGPDN

Novitasari, P. (2016). Pengaruh gaya kepemimpinan transformasional dan motivasi kerja terhadap kinerja karyawan. Jurnal Ilmu Dan Riset Manajemen, 5(9), 1-20.

Sardi. (2017). Pengaruh Gaya Kepemimpinan Transformasional Dan Transaksional Terhadap Kinerja Bawahan Melalui Kepuasan Kerja. Jurnal Bisnis Teori Dan Implementasi, 8(1), 61-72. 